\title{
FMO プログラムABINIT-MPの開発状況と機械学習との連携
}

望月 祐志 ${ }^{\mathrm{a}, \mathrm{b}^{*}}$, 坂倉 耕太 $^{\mathrm{c}}$, 秋永 宜伸 ${ }^{\mathrm{d}}$, 加藤 幸一郎 ${ }^{\mathrm{e}}$, 渡邊 啓正 ${ }^{\mathrm{f}}$, 沖山 佳生 ${ }^{\mathrm{g}}$, 中野達也 ${ }^{\mathrm{g}}$, 古明地勇人 ${ }^{\mathrm{h}}$, 奥沢明 ${ }^{\mathrm{i}}$, 福澤 薫 ${ }^{\mathrm{b}, \mathrm{j}}$, 田中成典 ${ }^{\mathrm{k}}$

\author{
a立教大学理学部化学科, $=$ 171-8501 東京都豊島区西池袋3-34-1 \\ ${ }^{\mathrm{b}}$ 東京大学生産技術研究所, $=153-8505$ 東京都目黒区駒場 4-6-1 \\ ${ }^{\mathrm{c}}$ 日本電気株式会社，广 108-8001 東京都港区芝 5-7-1 \\ $\mathrm{d}$ 株式会社ヴァイナス，广530-003 大阪市北区堂島2-1-31 \\ e みずほ情報総研株式会社，广101-8443 東京都千代田区神田錦町 2-3 \\ ${ }^{\mathrm{f}} \mathrm{HPC}$ システムズ株式会社，テ108-0022 東京都港区海岸3-9-15 LOOP-X 8 階

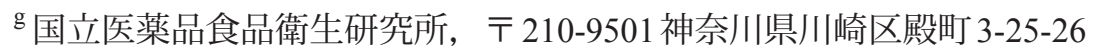 \\ $\mathrm{h}$ 産業技術総合研究所, $7305-8560$ 茨城県つくば市梅園 1-1-1 \\ ${ }^{\mathrm{i}}{ }^{2}$ 侏式会社ナレッジコミュニケーション，＝272-0143 千葉県市川市相之川3-13-23

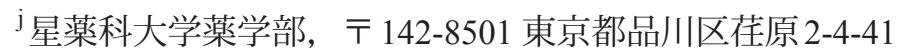 \\ ${ }^{k}$ 神戸大学大学院システム情報学研究科，＝657-8501 兵庫県神戸市灘区六甲台町 1-1 \\ *e-mail:fullmoon@rikkyo.ac.jp
}

(Received: December 4, 2017; Accepted for publication: December 25, 2017; Online publication: January 30, 2018)

We have been developing the ABINIT-MP program for the fragment molecular orbital (FMO) method. The list of inter-fragment interaction energies (IFIEs) is available from FMO calculations and is useful in analyzing the nature of interactions in a given target system. In this Letter, we summarize the current status of ABINIT-MP and also the machine-learning assisted analyses of IFIE data.

キーワード : Fragment molecular orbital, FMO, ABINIT-MP, Interaction energy, Machine learning

\section{1 序論}

巨大分子の"分割統合"系の種々の量子化学計算法 [1] の中で，フラグメント分子軌道(FMO)法 [2-4]は方法論 的な発展の多様性と応用事例の豊かさの点で最も普及し ていると言える．主なFMOプログラムとしては，米日 連携で推進されている GAMES-US [1,3]. が機能的には最 も充実しているが, 著者らが開発しているABINIT-MP [2,4-6]や長崎大の石川先生によるPAICS [7]も一般の利 用者が居られる.

FMO計算からは，フラグメント間の相互作用エネル ギー (GAMESS-USではPIE, ABNIT-MPとPAICSでは IFIE と呼ばれる)等の対象系の解析に好適な情報が得ら れることが, 生体分子系を中心に多数の応用事例 $[3,4]$ が報告されてきている理由にもなっている．これまでの ところ, タンパク質の相互作用解析はPDBからのダウ ンロードデータによる単一構造に基づくものがほとんど
だが，水中での構造摇らぎを考慮した統計的な検討 [7] が今後は重要となってくると考えられる. 実際のプロト コルとしては, 古典力場による分子動力学(MD)シミュ レーションによって得られる多数の構造サンプルに対 し, 一連のFMO計算を行うことになる. 単一構造の場 合と違い，こうして生成されるIFIEのデータ量は「人が 把握する」にはあまりにも膨大(いわゆるビッグデータ) となり得る。昨今のトレンドもあり,ここに機械学習を 導入して「人間が把握可能な量に簡約する」ことは自明 な流れとも言えるであろう.

この速報では, ABINIT-MPプログラムの最近の開発 • 整備の状況を前半に概説し, 後半ではマイクロソフト (MS)の Azure [8] と Googleの深層学習ツール TensorFlow [9]を使った IFIEデータの機械学習による解析事例 [10] をご紹介したい。 
Table 1. Timing data at OFP (HIV-1 protease).

\begin{tabular}{ccccc}
\hline \#Nodes & \#MPI & \#Thr. & Tot. \#Thr. & Time (m) \\
\hline 1 & 2 & 64 & 128 & 1922.8 \\
1 & 4 & 64 & 256 & 935.7 \\
2 & 2 & 64 & 256 & 967.2 \\
2 & 4 & 64 & 512 & 479.0 \\
4 & 4 & 64 & 1024 & 244.6 \\
4 & 16 & 4 & 256 & 562.0 \\
4 & 16 & 8 & 512 & 293.7 \\
4 & 16 & 16 & 1024 & 168.9 \\
4 & 8 & 32 & 1024 & 192.0 \\
8 & 16 & 16 & 2048 & 107.4 \\
8 & 8 & 32 & 2048 & 100.6 \\
\hline
\end{tabular}

\section{ABINIT-MPの状況}

ABINIT-MPは，旧公開用Ver.7までが東大生産研のサ イト [5]で Intel Xeon (IA64)用バイナリが(未だ)ダウン ロード出来るようになっている，ただ，2015年度から， Openシリーズとして文科省ポスト「京」プロジェクト (FS2020)の重点課題6の活動の中に開発・整備が移行し ている. 現在利用可能な版はOpen Ver.1 Rev.5 (2016年 12 月)で,「計算工学ナビ」のサイト [6]を参考に, 取り䌕 め責任者の望月にコンタクトをしていただき，個別対応 にてご提供している(形態はバイナリのみ, ソース込み の2通りある). HPCI関係では, 理研AICSの「京」, 東 工大の TSUBAME，東大・筑波大JCAHPCの OakForestPACS (以下OFP と略記), それに海洋機構CEIST の地球 シミュレータ(ES3)にライブラリとして提供済みとなっ ている.

Open Ver.1 Rev.5 は, 東大生産研系の旧Ver.7に比して メモリ関係を整理して動作の安定化が図られている。ま た，ヨウ素や白金などの重元素用に相対論効果を含むモ デル内殼ポテンシャル(MCP) [11]が使えるようになって いる.

OFPはIntel Xeon Phiの第2世代である Knights Landing (KNL)を用いたスーパーコンピュータである．搭載 KNL の物理コアの数は 68 であるが, ハイパースレッディン グ $(\mathrm{HT})$ 機構によって4倍までスレッド数を増やせる. ABINIT-MPによるFMO-MP2計算は，HTを活かして少 ないノード数で効率良く実行出来る. Table 1 に, HIV-1 proteaseの FMO-MP2/6-31G*エネルギー計算の OFP 上で のタイミングを示す．並列化は混成型で，フラグメント 内処理をOpenMPのスレッド単位(\#Thr.) で, フラグメン トのタスクリストをMPI単位(\#MPI)で制御しているが, 総スレッド数(Tot. \#Thr.)の増加に対する加速は良好であ る.

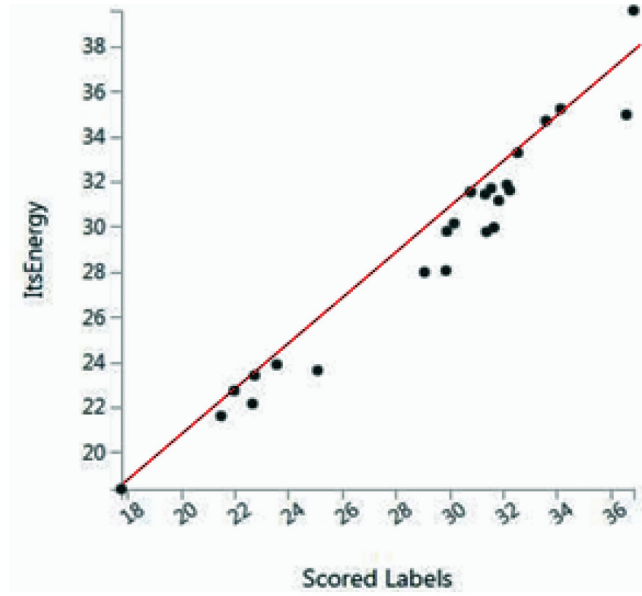

Figure 1. IFIE prediction (TrpCage).

2017年度末にリリース予定の Open Ver.1 Rev.10では, 相互作用エネルギーの成分解析 (PIEDA) [12]が導入さ れ，環境静電ポテンシャルの点電荷近似で Mulliken 電荷 だけでなくRESP電荷も使えるようになる，その後，フ ラグメント分割ポイント処理の多様化, 有効内殼ポテン シャル (ECP), B3LYPなどの機能が追加されていく予定 である。

\section{3 機械学習の利用}

これまでにIFIEデータの解析に Azure [8]の機械学習 を適用したタンパク質は, Chignolin (10残基), TrpCage (20残基), Ubiqutin (76残基), Calmodulin (148残基)で ある. 計算の基本的なワークフローは，(1) PDB構造を ベースに水素付加や対イオンと水を追加して周期条件 下で古典MDを行う，(2) 適当なインターバル (100ps等) で液滴モデルとして 100 個(程度)切り出す, (3) MP2/631G*レベルでFMO計算を実行する，(4) 一連の IFIEデー タをアミノ酸残基間の距離や残基の電荷などの記述子の 候補と共に取り出す，(5) 各残基対のIFIEを目的関数と して Azure [8]によるニューラルネットワーク回帰分析 にかける，(6) 解析結果を回収して整理する，となって いる。こうした統計的な解析によって，各々のアミノ残 基対のIFIEを特徴付けている記述子が決まるので，相互 作用の本質を整理するのに有益である [10].100個のサ ンプル数の場合, 現在の設定では 75 個のセットで学習

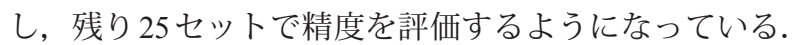
Figure 1 は TrpCageの荷電性アミノ酸残基の組み合わせと なるArg16-Lys8間のIFIEの評価25セットの結果で，好 ましい相関関係が見られる(単位は $\mathrm{kcal} / \mathrm{mol}$ で, 横軸が 予測值，緃軸が実際のIFIE值)。荷電性残基間のIFIEの 


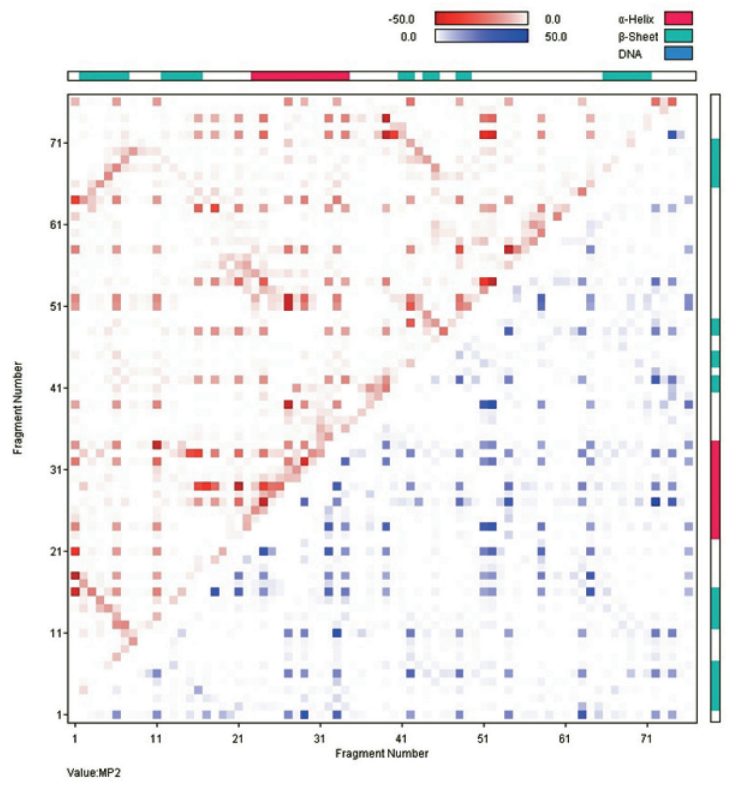

Figure 2. IFIE-map (Ubiquitin).

場合，記述子の中では電荷重心間の距離が主導的である ことが分かった。 ただし，非荷電-非荷電，荷電-非荷電 の残基対の場合には，未だ改良の余地があり，記述子候 補の追加などを今後進めていく.

深層学習ツールの TensorFlow [9]の応用では, IFIEmap [4]の自動解釈を試みた. IFIE-mapでは, タンパク 質の $\alpha$-ヘリックス, $\beta$-シートの構造は各々特徽的なパ ターンとして可視化される. Figure 2 は, 両構造が含ま れているUbiquitinの IFIE-mapの例で，䞑セルの上三角 が安定化, 青いセルの下三角が不安定化の領域で, 添え られたバーは連続二面角の構造から別途判定された $\alpha$ 一 リックス(赤)と $\beta$-シート(緑)を示している. TensorFlow への入力では, 画像処理によってこのバーは削除し, 行 列イメージのところのみとする. 実際のテストでは, 18 種類のタンパク質をPDBからダウンロードし, 古典 MD を行ってサンプル構造を50個程度集め, FMO-MP2/631Gレベルで計算を行って，IFIE-mapを調製した。 ま た，参照データとして非タンパク質も3 種類を用意 し, IFIE-mapの総数としては千枚を超える数を揃えた. TensorFlowの隠れ層の設定としては, 2層(Figure 3に図 示)と3層の両方を試みた，学習が終わった後で, 18 種 のタンパク質のIFIE-mapを判定させたところ, 画像読み 込子時の解像度が低いと $\alpha$-ヘリックスでは 2 層の方が確 度が高い場合があるが, 解像度を上げると2層, 3 層共 に確度は 1 に近づく $(\beta$-シートは $\alpha$-ヘリックスよりも判 定が容易). こうしたことから, 解像度と隠れ層の数を

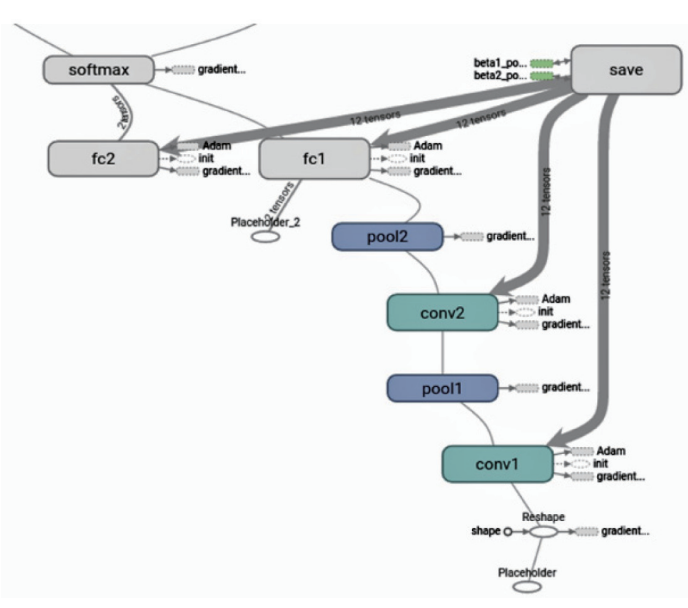

Figure 3. Layer structure of TensorFlow.

上手く設定する限り，TensorFlowによるIFIE-mapの識別 は上手く機能すると考えている [13].

\section{4 おわりに}

ここ数年で, 計算化学を含む数值シミュレーションと 機械学習/人工知能等のデータ科学との「融合」が進ん でいくであろう。その中では, 結果データの自動解析・ 解釈だけでなく,「実計算をしないで(桁違いに高速に) 定量的に予測する」技術一例えば，Quantum Machineに 出ているような試み [14]一も重要になっていきそうであ る. 創薬や分子設計などに関わる応用計算のあり方も, それに応じて変容するかもしれない. いずれにせよ, 計 算化学のコミュニティと情報科学・統計数理系のコミュ ニティとの連携が一層求められていくと思われる. こう した流れの中で, ABINIT-MPを軸とするFMO計算の進 め方を柔軟に変えていく必要もありそうである.

本研究開発は, 文科省ポスト「京」プロジェクト (FS2020)重点課題6, 並びに科研費(16H04635)からの支 援を受けている.

\section{参考文献}

[1] M. S. Gordon, D. G. Fedorov, S. R. Pruitt, L. V. Slipchenko, Chem. Rev., 112, 632 (2012). DOI:10.1021/ cr200093j

[2] D. G. Fedorov, K, Kitaura ed., "The Fragment Molecular Orbital Method: Practical Applications to Large Molecular Systems", 2009, CRC.

[3] D. G. Fedorov, et al., Phys. Chem. Chem. Phys., 14, 7562 (2012). DOI: $10.1039 / \mathrm{C} 2 \mathrm{CP} 23784 \mathrm{~A}$

[4] S. Tanaka, et al., Phys. Chem. Chem. Phys., 16, 10310 (2014). DOI: 10.1039/C4CP00316K 
[5] <http://www.ciss.iis.u-tokyo.ac.jp/software/>.

[6] <http://www.cenav.org/abinitmpopen1/>.

[7] T. Ishikawa, et al., J. Comput. Chem., 30, 2594 (2009). DOI: $10.1002 /$ jcc. 21265

[8] <https://azure.microsoft.com/ja-jp/>.

[9] <https://www.tensorflow.org/>.

[10] Y. Mochizuki, A. Okusawa, Keisankougaku, 22, 3539 (2017).
[11] T. Ishikawa, Y. Mochizuki, T. Nakano, S. Amari, H. Mori, H. Honda, T. Fujita, H. Tokiwa, S. Tanaka, Y. Komeiji, K. Fukuzawa, K. Tanaka, E. Miyoshi, Chem. Phys. Lett., 427, 159 (2006). DOI:10.1016/j.cplett.2006.06.103

[12] T. Tsukamoto, K. Kato, A. Kato, T. Nakano, Y. Mochizuki, K. Fukuzawa, J. Comput. Chem. Jpn., 14, 1 (2015). DOI:10.2477/jccj.2014-0039

[13] S. Saitou, submitted for publication.

[14] <http://www.quantum-machine.org/>. 